pressure is tiring and can be given only periodically. It offers a useful alternative to continuous mechanical ventilation plus positive end expiratory pressure when treatment is prolonged and the patient can breathe spontaneously. ${ }^{4}$ There are few reports on the use of continuous positive airway pressure in adults, but our case shows that it may be an alternative to continuous mechanical ventilation plus positive end expiratory pressure in treating the adult respiratory distress syndrome.

${ }^{1}$ Sevitt $S$. The significance and classification of fat embolism. Lancet 1960; ii :825-8.

${ }^{2}$ Burgher LW, et al. Fat embolism and the adult respiratory distress syndrome. Mayo Clin Proc 1974;49:107-9.

${ }^{3}$ Andersen J, Beck O, Brøckner J. Intermittent positive end expiratory pressure (PEEP) in the treatment of atelectasis. Ugeskr Laeger 1975; $137: 889-93$.

4 Vuori A, et al. Continuous positive airway pressure during mechanical and spontaneous ventilation. Acta Anaesthiol Scand 1979;23:453-61.

${ }^{5}$ Ashbaug DG, et al. Continuous positive-pressure breathing (CPPB) in adult respiratory distress syndrome. F Thorac Cardiovasc Surg 1969; $57: 31-41$.

(Accepted 4 March 1980)

Department of Surgery and Department of Anaesthesia, Roskilde Hospital, Denmark

LARS NAVER, $M D$, registrar in surgery

$S$ WALTER, MD, senior registrar in surgery

JANUSZ GLOWINSKI, MD, senior registrar in anaesthesia

\section{Interference of a propranolol metabolite with serum bilirubin estimation in chronic renal failure}

Some patients with chronic renal failure have shown consistently raised serum bilirubin concentrations, as measured by an automated diazo technique (SMA 12/60, Technicon Instruments). Hyperbilirubinaemia, however, was not detected with the Bilirubinometer (British American Optical Company), which uses a direct photometric technique rather than a chemical reaction. Since all of these patients had been given antihypertensive agents, we have investigated the possibility that this interference with the diazo reaction (which we have called "false bilirubin") was due to retention of a drug in chronic renal failure.

\section{Subjects, methods, and results}

We obtained a list from the department of chemical pathology of all patients in the five months from 20 March 1979 with raised serum bilirubin concentrations (over $14 \mu \mathrm{mol} / 1(0.84 \mathrm{mg} / 100 \mathrm{ml})$, diazo technique), normal liver function values (serum aspartate aminotransferase activity under 40 IU/l and alkaline phosphatase activity under $130 \mathrm{IU} / 1)$, and serum creatinine concentrations over $400 \mu \mathrm{mol} / 1(4.5 \mathrm{mg} / 100 \mathrm{ml})$. There were 21 such patients (table). All were suffering from chronic renal failure, and all but three were taking propranolol.

Stored, frozen sera obtaincd from 13 of the 21 patients, including two of the three patients not receiving propranolol, were retested using a diazo technique, ${ }^{1}$ and by the Bilirubinometer. All but one of the sera from patients taking propranolol showed abnormal diazo reactions and normal Bilirubinometer results, indicating the presence of "false bilirubin." The samples from the two patients who were not taking propranolol showed raised bilirubin concentrations when tested with both the Bilirubinometer and the diazo reaction. They therefore had true hyperbilirubinaemia. Thus all the patients with "false bilirubin" were taking propranolol.

We used 15 consecutive patients with chronic renal failure who were neither undergoing dialysis nor receiving propranolol as control subjects. Study of the case notes of these patients showed that they had never had hyperbilirubinaemia (diazo technique, data available from authors on request). The report by Andrewes ${ }^{2}$ of false-positive diazo reactions in uraemic sera almost certainly referred to patients who were more uraemic and had a more active catabolism than ours.

Serial studies on several patients receiving a constant dose of propranolol showed that there was a relation between the "false bilirubin" concentration and the serum creatinine concentration. When haemodialysis was started the "false bilirubin" values fell, despite the continued administration of propranolol. Peritoneal dialysis did not seem as effective in removing this substance.
The table shows that 13 of the 21 patients were taking hydralazine. We found, however, that neither hydralazine itself nor eight known metabolites interfered with the diazo reaction. We also found that propranolol itself did not interfere with the diazo reaction, but that two of its metabolites, 4-hydroxypropranolol and 1-naphthol, gave false-positive results. 4-Hydroxypropranolol is a major hepatic metabolite of propranolol and is excreted in the urine as glucuronide and sulphate conjugates. ${ }^{3}$

Several serum samples from our patients were treated with glucuronidase and sulphatase, which deconjugate these compounds, and were examined by two-dimensional thin-layer chromatography. This showed that the substance in these sera that reacted with the diazo reagent had, after deconjugation, identical chromatographic properties to 4-hydroxypropranolol.

Propranolol dose and serum bilirubin and creatinine concentrations in 21 uraemic patients with apparent hyperbilirubinaemia

\begin{tabular}{|c|c|c|c|c|}
\hline \multirow[b]{2}{*}{ Case } & \multirow{2}{*}{$\begin{array}{c}\text { Propranolol } \\
\text { (mg/day) }\end{array}$} & \multicolumn{2}{|c|}{ Bilirubin $(\mu \mathrm{mol} / \mathrm{l})$} & \multirow{2}{*}{$\begin{array}{l}\text { - Creatinine } \\
(\mu \mathrm{mol} / \mathrm{l})\end{array}$} \\
\hline & & Diazo technique & Bilirubinometer & \\
\hline $1^{*}$ & 0 & 21 & & 730 \\
\hline 2* & 0 & 34 & . 30 & 615 \\
\hline $3+$ & 0 & 48 & 40 & 960 \\
\hline $4^{*}$ & 1280 & 25 & & 465 \\
\hline $5^{*}$ & 640 & 15 & & 595 \\
\hline 6 & 480 & 25 & & 1565 \\
\hline $\begin{array}{l}7 \\
8\end{array}$ & $\begin{array}{r}1280 \\
160\end{array}$ & 23 & & $\begin{array}{l}545 \\
525\end{array}$ \\
\hline 9 & 360 & $\begin{array}{l}18 \\
18\end{array}$ & $<10$ & 605 \\
\hline $10^{*}$ & 1280 & 51 & $<10$ & 1030 \\
\hline 11 & 1280 & 74 & & 1105 \\
\hline $12^{*+}$ & 1280 & 33 & $<10$ & 655 \\
\hline $13^{*}$ & 640 & 19 & $<10$ & 560 \\
\hline $14^{*}$ & 640 & 36 & & $\begin{array}{r}675 \\
1285\end{array}$ \\
\hline $15^{*} \dagger$ & 640 & 33 & $<10$ & 1285 \\
\hline $16^{*}$ & $\begin{array}{l}1280 \\
1280\end{array}$ & 22 & $\begin{array}{r}15 \\
<10\end{array}$ & $\begin{array}{l}440 \\
950\end{array}$ \\
\hline $18^{+}$ & 640 & 15 & $<10$ & $\begin{array}{l}950 \\
760\end{array}$ \\
\hline $19^{*}$ & 320 & 23 & $<10$ & 1255 \\
\hline $20 \pm$ & 1280 & 57 & $<10$ & 465 \\
\hline $21^{*} \S$ & 1280 & 60 & 20 & 680 \\
\hline
\end{tabular}

*Patient taking hydralazine.

+ Patient underwent peritoneal dialysis.

$\$$ Patient underwent haemodialysis.

$\S$ Lipaemic serum.

Conversion: SI to traditional units-Serum bilirubin: $1 \mu \mathrm{mol} / 1 \approx 0.06 \mathrm{mg} / 100 \mathrm{ml}$. Serum creatinine: $1 \mu \mathrm{mol} / 1 \approx 0.01 \mathrm{mg} / 100 \mathrm{ml}$.

\section{Comment}

We have shown that a propranolol metabolite, a conjugate of 4hydroxypropranolol that is normally excreted in the urine, accumulates in the plasma of undialysed patients with chronic renal failure and interferes with the widely used diazo reaction to give falsely raised bilirubin concentrations, which may cause confusion clinically and lead to unnecessary investigations. The Bilirubinometer, available in most neonatal units, provides a simple way of avoiding this source of error.

We thank Dr A J Pinching for encouraging us to undertake this study and discussing it with us, the department of chemical pathology for permission to use their results, and Professor D K Peters for allowing us to study patients under his care.

\section{Addendum}

Since this study was completed a report ${ }^{4}$ has appeared of a similar phenomenon, proposing that the false hyperbilirubinaemia is due to an unidentified metabolite of propranolol.

${ }^{1}$ Michaëlsson M. Bilirubin determination in serum and urine. Scand $\mathcal{f}$ Clin Lab Invest $1961 ; 13$, suppl:56.

${ }^{2}$ Andrewes $\mathrm{CH}$. An unexplained diazo-colour-reaction in uraemic sera. Lancet $1924 ; 206: 590-1$.

${ }^{3}$ Walle T, Gaffney TE. Propranolol metabolism in man and dog: mass spectrometric identification of six new metabolites. $\mathcal{f}$ Pharmacol Exp Ther $1972 ; 182: 83-92$.

${ }^{4}$ Stone WJ, McKinney TD, Warnock LG. Spurious hyperbilirubinemia in uremic patients on propranolol therapy. Clin Chem 1979;25:1761-5.

(Accepted 14 February 1980)

Department of Medicine, and Department of Paediatrics and Neonatal Medicine, Hammersmith Hospital, London W12 0HS

SAAD AL-DAMLUJI, BSC, MB, senior house officer (now senior house officer, department of medicine, St Bartholomew's Hospital, London EC1A $7 \mathrm{BE})$

JOHN H MEEK, BSC, senior biochemist 